\title{
SOCIAL CAPITAL NETWORKS, MICROCREDIT AND POVERTY STATUS OF RURAL HOUSEHOLDS IN NIGERIA
}

\author{
Ayodeji Sunday Ogunleye ${ }^{\mathrm{l}}{ }$, Remi Adeyemo $^{1}$ \\ ${ }^{1}$ Obafemi Awolowo University, Nigeria
}

\begin{abstract}
This study examined how social capital networks contribute to rural household poverty status in south-western Nigeria. A multistage sampling procedure was used to select a total of 300 households for this study. A structured questionnaire was used to obtain information and data were analysed using descriptive statistics, Foster, Greer and Thorbecke (FGT) poverty measure and Two-Stage Least Square model (2SLS). Results showed that poverty incidence, depth and severity were $60 \%, 46.70 \%$ and $20.10 \%$, respectively, among the households sampled. The results indicated that social capital network forms in the study area include cooperative societies, family and friends, farmer associations, as well as professional, religious and microfinance groups. The results also showed that $66.00 \%$ of the households in the study area sourced microcredit from cooperative societies. The 2SLS estimate showed that the coefficient of the aggregate social capital index $(\beta=730.83, p<0.05)$ showed a positive, significant relationship with household per capita expenditure. The result indicated that a one-unit increase in social capital network index of the household would increase household per capita expenditure in the study area by NGN 730.83 (USD 1.92). The study concluded that social capital network membership positively affects the households' access to microcredit and helps reduce poverty.
\end{abstract}

Keywords: microcredit, poverty reduction, rural households, social capital networks

\section{INTRODUCTION}

Poverty remains one of the greatest problems of today's world and there are more than three billion people in the world living below USD 2 per day, one and a half billion people living below USD 1 per day, and 70-90 per cent of people in the developing countries are impoverished (Chen and Ravallion, 2010; Osborn et al., 2015). Consequently, one of the United Nations' major sustainable development goals (SDGs) is to drastically reduce the percentage of people living in poverty by the end of 2030 (World Bank Group, 2014). According to the Joseph Rowntree Foundation (2013), poverty has been defined in a way that only considers material deprivation (measured by an appropriate concept of income or consumption). It is described as the inability of individuals to access a minimum acceptable standard of living in society.

The World Bank estimates (World Bank, 2014) of the poverty level in Nigeria showed that the number of the poor and food-insecure remained very high, and between 33.1 and 70.2 per cent of the country's population were severely impoverished. The poverty profile further indicated that $87 \%(1985), 67 \%(1992), 70 \%(1996)$, $46.5 \%$ (2010) and $44.9 \%$ (2014) of the poor lived in rural areas and typically worked in agriculture (NBS, 2010; World Bank, 2014). Thus, poverty in Nigeria is predominantly a rural phenomenon and addressing it requires

\footnotetext{
$\bowtie$ Ayodeji Sunday Ogunleye, Department of Agricultural Economics, Faculty of Agriculture, Obafemi Awolowo University, Ile-Ife, Osun State, Nigeria, e-mail: ogunleyedeji@oauife.edu.ng; https://orcid.org/0000-0003-0193-027X
} 
focusing on the rural population (Hassan and Birungi, 2011). Some studies (Balogun et al., 2011; Iyanda et al., 2014) have already identified the causes of poverty, which include low productivity and limited access to investment capital. This makes it difficult - if not impossible - for rural households to optimally utilise their limited resources to generate higher income (Iyanda et al., 2014).

Between 1977 and today, governments have initiated different policies and structural programmes to overcome Nigeria's poverty problem (Adepoju and Oni, 2012). These programmes were aimed at alleviating the suffering of the poor by providing them with employment opportunities and enabling them to establish their own businesses. As part of the efforts at bridging the poverty gaps prevalent among rural households, it was determined that the lack of access to microcredit is a major constraint to their growth, investments and poverty reduction (Ugbaja and Ugwumba, 2013). The launch of microcredit schemes in Nigeria was considered a milestone on the road to eradicating poverty (Adepoju and Oni, 2012). This was based on the assumption that the poor lacked the money needed for investments while being unable to save any at the same time, and as such, they could neither develop their business nor adopt new technologies without external funding sources (Awojobi and Bein, 2011).

Access to microcredit strengthens the productive assets of the poor by enabling them to secure adequate investment capital, which can be used to further invest in productivity-enhancing new technologies (Balogun et al., 2011). Studies (Bastelaer, 2000; Balogun et al., 2011) have established that social networks and interactions are one of the platforms that could help to facilitate access to microcredit among rural households. Sociologists and economists (Oke et al., 2007; Conley and Udry, 2010) emphasized the important role played by social networks in facilitating rural development through streams of benefits. Social networks create social capital, which has been defined as closely connected social relations that provide individuals and groups with access to productive resources (Imandoust, 2011).

This social relation is often structured through the creation of local associations or local institutions (Adepoju and Oni, 2012). Such interactions and social networks can lower the household's expenses, improve its welfare by increasing information flows, reduce transaction costs, as well as create skill acquisition and enhancement platforms (Oke et al., 2007; Imandoust, 2011; Balogun et al., 2011). They also improve credit market accessibility through social enforcement and social collateral mechanisms, particularly among the poor living in rural areas (Karlan, 2007; Karlan et al., 2009). This indicates that social capital network is becoming a critical factor in providing access to microcredit and other inputs. Hence, it could provide a sound basis for alleviating poverty through improved access to investment capital among Nigeria's rural households (Adepoju and Oni, 2012).

\section{MATERIAL AND METHODS}

\section{Study area}

This study was carried out in south-western Nigeria (see Fig. 4). The south-western (SW) part of Nigeria represents a geographical area located between latitude 60 north and 40 south, as well as longitude 40 west and 60 east. It covers a land area of approximately $114,271 \mathrm{~km}^{2}$, which represent about $12 \%$ of the country's total land area and includes six states which are Ekiti, Oyo, Ogun, Ondo, Lagos and Osun (see Fig. 1 below). The region is bounded by the Kogi and Kwara States to the north, the Atlantic Ocean to the south, the Republic of Benin to the west and the Edo and Delta states to the east. Its total population is $27,581,992$ and its incidence of poverty is very low compared to other geopolitical zones in the country, with the food poverty at about $25.4 \%$, absolute

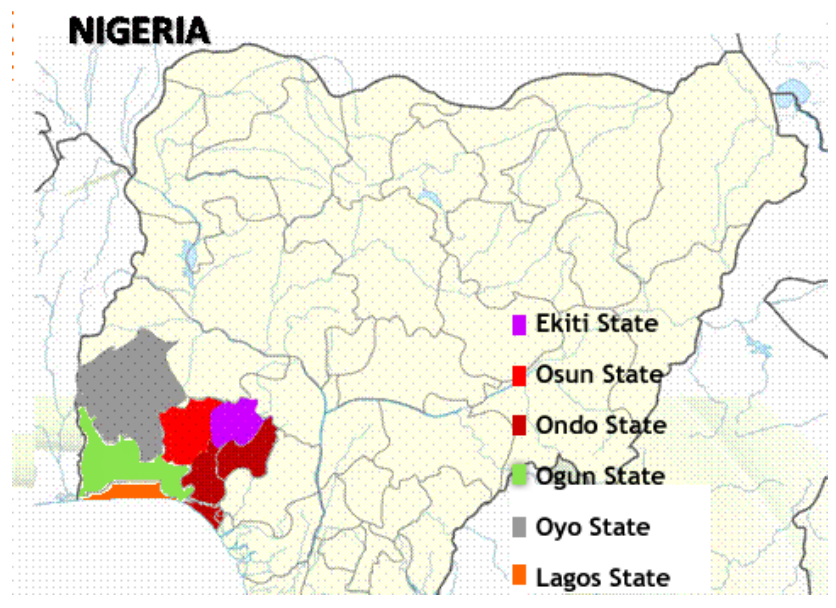

Fig. 1. Map of Nigeria showing the south-western states Source: Google Map. 
poverty at $49.8 \%$, and relative poverty at $59.1 \%$ (NBS, 2010). The Osun state has the lowest absolute poverty level within the region at $37.9 \%$ while Ekiti and Oyo ranked the highest, with the absolute poverty figure of approximately $52.0 \%$. Both men and women engage in farming, trading and other economic activities and are members of different social and microcredit groups operating within the region.

\section{Sampling procedures}

A multistage sampling procedure was used; the first stage involved simple random sampling of three states from south-western Nigeria. The second stage involved choosing three senatorial districts from each state. The third stage involved a simple random selection of two Local Government Areas (LGAs) from each of the three senatorial districts for a total of eighteen LGAs. This was necessary for equal representation of household social capital networks. The fourth stage consisted in a random selection of between one and three functional Social Capital Networks (SCNs) in each LGA based on their size for a total of thirty SCNs. The proportionality factor that was used in the selection of social capital networks is as follows:

$$
X_{i}=[n / N] \cdot 30
$$

where:

$X_{i}$ - the number of social capital networks sampled from each LGA

$n$ - the total number of social capital networks in the particular LGA where the samples were drawn

$N$ - the total number of social capital networks in all LGAs sampled for this study.

The desired total number of social capital networks from the three states was 30 . The final stage of sampling involved a random selection of ten (10) households in each of the selected social capital networks. A total of 300 households were interviewed for this study.

\section{Data collection methods}

This study used primary data. A structured questionnaire was developed and used to obtain information from each household selected. The data was collected in the Oyo, Osun and Ondo states in the early part of the year 2016. A total of 300 households participated in the survey with the household head representing each of them. The questionnaire used included information on the socioeconomic and demographic characteristics of the households, social capital participation, household income and expenditure profiles, microcredit variables and asset valuation variables. The questionnaire was pre-tested and validated to ensure its suitability and usability.

\section{Data analysis techniques}

Data were analysed using descriptive statistics, Foster, Greer and Thorbecke poverty measure, Heckman selection model, and the two-stage least square (2SLS) model; additionally, different social capital dimensions indices were used. The details on how to construct such indices could be found in Lawal et al. (2009).

\section{Poverty measure and poverty line estimation}

The poverty line is the level of expenditure that distinguishes poor households from non-poor households. This is a pre-determined and well-defined standard threshold income or value of consumption (expenditure). The choice of an expenditure-based rather than an income-based measure of household expenditure for this study was motivated by the fact that income can be viewed as a measure of either expenditure opportunity or expenditure potential while expenditure can be interpreted as either an expenditure incurred or a measure of expenditure achievement (Meyer and Sullivan, 2003). The Foster et al. (1984) poverty measure was employed in this study to estimate the poverty indices. The respondents' per capita expenditures were used to classify them into three categories, i.e.: poor, non-poor and core poor. The FGT measure for the $i^{\text {th }}$ subgroup is as follows:

$$
\begin{gathered}
P \alpha_{i}=\frac{1}{n_{i}} \sum_{j=i}^{q}\left[\frac{Z-X_{i j}}{Z}\right]^{\alpha} \\
P_{0}=\frac{1}{n_{i}} \sum_{j=i}^{q}\left[\frac{Z-X_{i j}}{Z}\right]^{\alpha}
\end{gathered}
$$

where:

$Z$ - poverty line (which was the $2 / 3^{\text {rd }}$ of the average monthly expenditure)

$X_{i j}-$ per capita expenditure of the household $i(i=1$, $2, \ldots, q)$

$q$ - number of households below the poverty line

$n$ - total number of households sampled

$\alpha$ - poverty aversion parameters of the FGT index $\left(P \alpha_{i}\right), \alpha \geq 0$, which can take three values: 0,1 , and 2 . 
The implications of the values $\alpha$ are as follows:

$$
P \alpha_{i}=q_{i} / n_{i}
$$

where $\alpha=0$ (head count ratio or incidence of poverty) the proportion of the respondents' household that is poor. $\alpha=1$, poverty depth (or the proportion of the expenditure shortfall from the poverty line), and $\alpha=2$, poverty severity (or the amount of expenditure transfer between a poor and a poorer household required for poverty to decrease). The explanatory variables $\left(X_{s}\right)$ used were defined as below.

\section{Household characteristics}

$X_{1}$ (AGE) - age of the household head (years), $X_{2}$ (AGESQUD) - age of the household head squared (years) ${ }^{2}$, $X_{3}$ (GEND) - gender of the household head $(D=1$ for male, otherwise $\mathrm{D}=0), X_{4}(\mathrm{EDU})$ - years of education of the household head (years), $X_{5}$ (DEPENRAT) - dependency ratio (the ratio of the unemployed household members (aged 0-14 and above 65 years old) to members belonging to an active working-class group (15-54 years), $X_{6}$ (HSIZE) - household size (\#), $X_{7}$ (MSTAUS) - the marital status of the household head ( $\mathrm{D}=1$ if married, $0=$ otherwise), $X_{8}$ (ASSET) - household asset (total value of the household's assets) (N), $X_{9}$ (PERCAPITA)-householdaveragemonthlyexpenditure (N), $\mathrm{X}_{10}$ (HINCOME) - household monthly income (N).

\section{Microcredit variables}

$X_{11}$ (CREDITGAP) - household monthly credit need/ gap (N), $X_{12}$ (INTEREST) - annual loan interest (\%), $X_{13}$ (TIMLAG) - time lag between credit request and delivery (month), $X_{14}$ (DISTAC) - the distance between the place of dwelling and credit source $(\mathrm{km}), X_{15}$ (PAYBACK) - payback period (month), $X_{16}$ (OWNSAVIN) household monthly savings $(\mathrm{N})$.

\section{Social capital variable}

$X_{17}$ (ATTEND) - association meeting attendance by households (\%), $X_{18}$ (DECID) - decision-making index within the association (\%), $X_{19}$ (CASHID) - cash contribution index of households to the association (\%), $X_{20}$ $(\mathrm{LABORID})=$ labour contribution index of households to the association (\%), $X_{21}$ (HETEROID) - association heterogeneity index $(\%), X_{22}$ (MEMBID) - membership density index of households to the association (\%). This study followed the definitions adopted by Grootaert (1999) and Balogun et al. (2011).
Two-stage least square model: the impact of social capital networks on household expenditure

Some linear models with endogenous explanatory variables are most easily estimated using the Two-Stage Least Square method and the latter can also be used to handle endogeneity in models with linear parameters. However, differences occur in the case of models with nonlinear endogenous variables - even if they have linear parameters. The estimation methods applied in this study are summarised algebraically below, based on Ajakaiye and Mwabu (2007).

$$
\begin{gathered}
E=g_{1} \delta_{e}+\beta S C+y M C+\varepsilon_{1} \\
S C=f \delta_{s c}+\varepsilon_{2} \\
M C=f \delta_{m c}+\varepsilon_{3} \\
P=1\left(f \delta_{p}+\varepsilon_{4}\right)>0
\end{gathered}
$$

where:

$E \quad$ - average monthly expenditure (

$S C$ - aggregate social capital (\%)

$M C$ - the average amount of microcredit received by households $(\mathrm{N})$

$P \quad$ - indicator function

$g \quad-$ vector of exogenous covariates

$f \quad-$ exogenous variables.

$S C, M C, P$ and $g_{1}-$ are vectors of instrumental variables which affect social capital (SC) but have no direct influence on expenditure

$E, \delta, \beta$ and $\varepsilon-$ are vectors of parameters to be estimated and a disturbance term.

To accommodate the non-linear interactions of the unobservable variables with the expenditure regressands, the complementarity between social capital, microcredit and other factors affecting expectations can be presented as follows:

$$
\begin{gathered}
E=\alpha_{0}+g_{1} \delta+\beta S C+y M C+\alpha_{1} V_{1}+\alpha_{2} V_{2} \\
+\gamma\left(V_{1} \times S C\right)+\theta(S C \times R)+\gamma\left(V_{2} \times M C\right) \\
+\theta(M C \times R)+\mu \ldots
\end{gathered}
$$

where:

$V_{1}-$ is the fitted residuals of social capital and microcredit which are derived from a linear probability model, i.e. observed value minus the fitted value,

$\left(V_{1} \times S C\right)$ and $\left(V_{2} \times M C\right)-$ is the interaction of the fitted social capital and microcredit variables 
with the actual value of the social capital and microcredit variables

$R$ - the exogenous variables such as donation, religion and length of stay, which are correlated with social capital, microcredit

$\mu$ - the composite error term.

\section{RESULTS AND DISCUSSION}

\section{Estimated incidence, depth and severity of poverty}

Table 1 shows the values of the poverty indicators, poverty incidence (Head-count index $(\mathrm{H})$ ), poverty gap index (PG - poverty depth and severity) and FosterGreer-Thorbecke's measure of poverty severity $\left(\mathrm{P}_{2}\right)$. The poverty line (Z) was computed using the $2 / 3^{\text {rd }}$ of the households' average expenditure approach. The poverty line of the household in the study area was N11,877.00 $( \pm 7,066.80)$. The proportion of the households below the poverty line was $60 \%$ while the proportion of the household above the poverty line was $40 \%$. This implied that $60 \%$ of the households sampled in the study area were poor. These figures showed that the level of poverty in south-western Nigeria had increased tremendously compared to the absolute poverty values of $49.80 \%$ (poor) recorded in the study area in 2010 by Nigeria's National Bureau of Statistics (NBS, 2010).

Table 1. Poverty parameters of households in the study area

\begin{tabular}{lcc}
\hline Poverty indicators & Frequency & $\begin{array}{c}\text { Average monthly per } \\
\text { capita expenditure ( })\end{array}$ \\
\hline Poverty incidence & 0.600 & - \\
Poverty depth & 0.467 & below 5,549.58 \\
Poverty severity & 0.200 & below 2,389.91 \\
\hline
\end{tabular}

Source: field survey, 2016.

The poverty gap index $\left(P_{1}\right)$ measures the extent to which households fall below the poverty line (the poverty gaps) as a proportion of the poverty line. The sum of these poverty gaps provides the minimal cost of eliminating poverty if transfers were perfectly targeted. The measure does not reflect the inequality among the poor (World Bank, 2005). Results showed that the poverty depth among the households sampled was $46.70 \%$. This implied that the percentage of the households that could afford per capita expenditure of NGN 5,549.58 among the households sampled was $46.70 \%$. This value was very low when compared with a $57.58 \%$ poverty depth (NBS, 2010). The implication was that between 2010 and 2016 the number of households that could afford a particular level of expenses had reduced by $10.88 \%$. The poverty severity among the households sampled showed a value of $20.10 \%$, which implied that the percentage of the households in the study area that could afford the expense of NGN 2,389.91 was $20.10 \%$.

\section{Sources and proportion of microcredit accessed by households in the study area}

Fig. 2 shows the distribution by the sources of microcredit and the percentage of households utilising the sources in the study area. The results indicated that microcredit sources in the study area included cooperative societies, farmer organisations, family and friends, professional career groups, religious groups, and microfinance groups (e.g. microfinance bank). The results also showed that $66.00 \%$ of the households in the study area sourced their microcredit needs from cooperative societies. This implied that the majority of the households in the study area belonged to cooperative societies. About $16.00 \%$ of the households sourced their microcredit from farmer organisations.

The above findings implied that farming was one of the primary occupations among the members of households in the study area and a certain level of cooperation

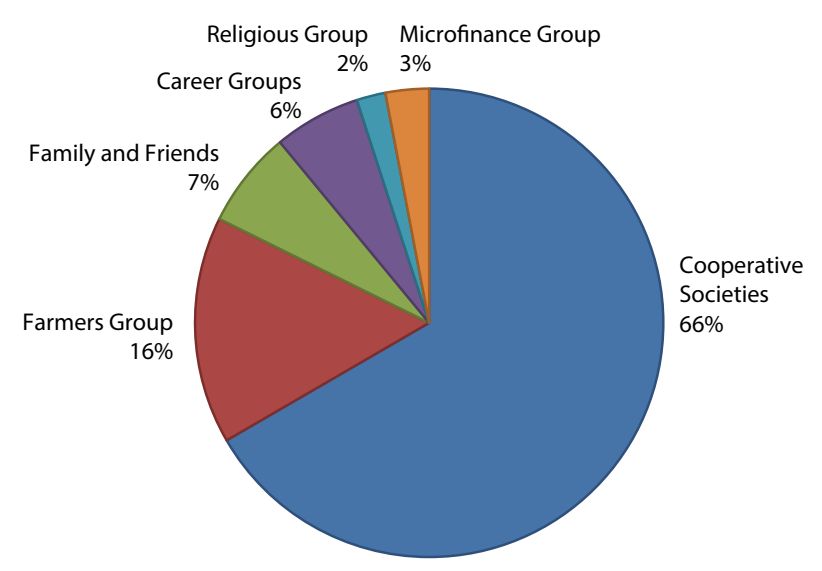

Fig. 2. Sources of microcredit among the households in the study area

Source: own elaboration. 
Ogunleye, A. S., Adeyemo, R. (2020). Social capital networks, microcredit and poverty status of rural households in Nigeria. J. Agribus. Rural Dev., 4(58), 369-378. http://dx.doi.org/10.17306/J.JARD.2020.01346

and trust existed even within different career/profession$\mathrm{al} /$ occupational groups in the study area. About $3.00 \%$ of the households sourced their microcredit needs from microfinance institutions. This indicated that the operational and supportive presence of microfinance institutions in rural areas was very insignificant.

\section{Household participation in social capital networks and microcredit groups}

Table 2 shows the distributions based on the households' participation in social capital networks in the study area. An analysis of the households' participation in social capital networks in the study area indicated that an average household had spent $8.47( \pm 7.71)$ years as a network member. The result further showed that about $45.70 \%$ of all households sampled had spent more than five years as members of such networks. The minimum and the maximum number of years spent by the households in these groups were zero and 52.00 years, respectively. This implied that participation in social capital networks in the study area was not a new concept. It also indicated a high level of understanding of the principles, practices and importance of social capital formation among households that had spent more than ten years as members of such social capital networks. The distribution according to the government involvement level showed that only $17.30 \%$ of these groups were controlled and regulated by the government. Thus, $82.70 \%$ of the social capital networks in the study area were not under any kind of government oversight. This implied that social capital networks in the study area utilised internal mechanisms (e.g. norms, beliefs and value systems) that regulated the various interactions among the individual members. One of the major factors in the formation of social capital networks is the common interest shared by individual group members. The distribution based on the individual households' reasons for joining any of these social capital networks indicated that $43.00 \%$ of the households sampled joined these networks to improve their access to microcredit while $34.00 \%$ joined such groups (trade groups) to gain professional acceptance and recognition that could boost their business activities.

About $16.00 \%$ indicated that they joined the groups to enhance their skills through the training and empowerment programmes they provide. About $2.70 \%$ of the households sampled indicated that they joined the social capital networks to socialise and enjoy various levels of
Table 2. Household participation in social capital networks

\begin{tabular}{lcc}
\hline \multicolumn{1}{c}{ Variable } & Frequency & Percentage (\%) \\
\hline Years of membership (Years) & & \\
\hline $1-5$ & 163 & 54.3 \\
$6-10$ & 87 & 29.0 \\
$11-15$ & 43 & 14.3 \\
Above 15 & 7 & 2.4 \\
Total & 300 & 100.0 \\
Mean (Std. Dev.) & 8.47 ( \pm 7.71$)$ \\
Government regulated? (Yes) & 52 & 17.3 \\
\hline Reasons for joining the group & & \\
\hline No reason & 13 & 4.3 \\
Access to microcredit & 129 & 43.0 \\
Business growth & 102 & 34.0 \\
Group actions (socialisation) & 8 & 2.7 \\
Empowerment and training & 48 & 16.0 \\
Total & 300 & 100.0 \\
Reason met? (Yes) & 280 & 93.3 \\
\hline Membership status & & \\
\hline Active & 183 & 61.0 \\
Total & 300 & 100.0 \\
Group providing training? (Yes) & 142 & 47.3 \\
\hline & & \\
\hline
\end{tabular}

Source: field survey, 2016.

group actions. Such group actions include those related to clubs, political parties, age-based group activities and others. However, the remaining $4.30 \%$ of households joined to take advantage of the bandwagon effect. These findings confirmed the principles of cooperation and social interactions, which claim that people join social capital networks to achieve specific objectives.

As a follow up on the reasons given for joining social capital networks, households were asked if their expectations had been met. About $93.30 \%$ indicated that their reasons for joining these groups had been met while $6.70 \%$ indicated the contrary. The distribution of the social capital networks based on providing training opportunities and capacity-building programmes indicated that $47.30 \%$ of the groups in the study area 
Ogunleye, A. S., Adeyemo, R. (2020). Social capital networks, microcredit and poverty status of rural households in Nigeria. J. Agribus. Rural Dev., 4(58), 369-378. http://dx.doi.org/10.17306/J.JARD.2020.01346

provided training and capacity-building opportunities for their members. This implied that some of the household members belonging to social capital networks that provided training opportunities had a chance to acquire additional skills to improve their livelihoods.

\section{Microcredit amount obtained from social capital networks}

Table 3 shows the distributions of the households according to the amount of microcredit obtained from social capital networks. The result showed that the average amount of microcredit obtained by households belonging to cooperative societies was $\$ 36,338.33$ ( \pm 14 202.92). In about $79.00 \%$ of cases, the microcredit obtained from cooperative societies was less than N100,000.00. This implied that the majority of entities taking advantage of cooperative society microcredit were probably micro and small scale businesses, which required moderate amounts of credit to start or expand their operations. The result also indicated that the average amount of microcredit obtained from the farmer groups was $\$ 48,069.66( \pm 16,631.96)$.

Farmer groups provided the highest amount of microcredit compared to other sources in the study area. More than $59.00 \%$ of the microcredit amounts obtained from farmer groups were below $\$ 100,000$.00 while in $40.40 \%$ cases they ranged from $\$ 100,000.00$ to $\mathrm{N} 200,000.00$. This implied that farmers probably required high capital outlays for their businesses. The average amount of microcredit obtained from family and friends was $\$ 6,000.00$ ( $\pm 2,571.50$ ). In about $90.00 \%$ of cases, such microcredit was less than $\$ 10,000.00$. Thus, on average, family and friends provided the smallest amount of microcredit for households in the study area. This implied that most of the microcredit obtained from such sources was probably used for consumption expenditures or combined with credit from other sources. Professional career groups provided $\mathrm{N} 35,921.30$ ( $\pm \mathrm{N} 13,302.06$ ), which constituted the third-highest volume of microcredit made available for households

Table 3. Distributions of households by the amount of microcredit obtained from social capital networks

\begin{tabular}{|c|c|c|c|c|c|c|c|c|c|c|c|c|}
\hline \multirow[t]{2}{*}{ Sources } & \multicolumn{2}{|c|}{$\begin{array}{l}\text { Cooperative } \\
\text { groups }\end{array}$} & \multicolumn{2}{|c|}{ Farmer groups } & \multicolumn{2}{|c|}{$\begin{array}{l}\text { Family and } \\
\text { friends }\end{array}$} & \multicolumn{2}{|c|}{$\begin{array}{l}\text { Professional } \\
\text { career groups }\end{array}$} & \multicolumn{2}{|c|}{ Religious groups } & \multicolumn{2}{|c|}{$\begin{array}{l}\text { Microfinance } \\
\text { groups }\end{array}$} \\
\hline & Freq & $\%$ & Freq & $\%$ & Freq & $\%$ & Freq & $\%$ & Freq & $\%$ & Freq & $\%$ \\
\hline $\begin{array}{l}\text { Below } \\
\$ 10,000.00\end{array}$ & 18 & 9.0 & 8 & 17.0 & 18 & 90.0 & 5 & 27.8 & 4 & 66.7 & 2 & 22.2 \\
\hline $\begin{array}{l}\text { N 10,001.00- } \\
100,000.00\end{array}$ & 140 & 70.0 & 20 & 42.6 & 1 & 0.5 & 11 & 61.1 & 2 & 33.3 & 7 & 77.8 \\
\hline $\begin{array}{l}\text { 100,001.00- } \\
150,000.00\end{array}$ & 36 & 18.0 & 12 & 31.9 & 1 & 0.5 & 1 & 5.6 & 0 & 0.0 & 0 & 0.0 \\
\hline $\begin{array}{l}\text { N } 150,001- \\
200,000.00\end{array}$ & 0 & 0.0 & 4 & 8.5 & 0 & 0.0 & 0 & 0.0 & 0 & 0.0 & 0 & 0.0 \\
\hline $\begin{array}{l}\text { 200,001.00- } \\
250,000.00\end{array}$ & 5 & 2.5 & 0 & 0.0 & 0 & 0.0 & 0 & 0.0 & 0 & 0.0 & 0 & 0.0 \\
\hline $\begin{array}{l}\text { 250,001.00- } \\
300,000.00\end{array}$ & 1 & 0.5 & 0 & 0.0 & 0 & 0.0 & 1 & 5.6 & 0 & 0.0 & 0 & 0.0 \\
\hline $\begin{array}{l}\text { Above } \\
\approx 300,000.00\end{array}$ & 0 & 0.0 & 0 & 0.0 & 0 & 0.0 & 0 & 0.0 & 0 & 0.0 & 0 & 0.0 \\
\hline Total & 200 & 100.0 & 47 & 100.0 & 20 & 100.0 & 18 & 100.0 & 6 & 100.0 & 9 & 100.0 \\
\hline $\begin{array}{l}\text { Mean } \\
\text { (std. dev.) }\end{array}$ & \multicolumn{2}{|c|}{$\begin{array}{c}36,338.33 \\
(14,202.92)\end{array}$} & \multicolumn{2}{|c|}{$\begin{array}{c}48,069.66 \\
(16,631.96)\end{array}$} & \multicolumn{2}{|c|}{$\begin{array}{c}6,000 \\
(2,571.50)\end{array}$} & \multicolumn{2}{|c|}{$\begin{array}{c}35,921.30 \\
(13,302.06)\end{array}$} & \multicolumn{2}{|c|}{$\begin{array}{c}7,453.70 \\
(2,547.56)\end{array}$} & \multicolumn{2}{|c|}{$\begin{array}{c}11,022 \\
(4,791.13)\end{array}$} \\
\hline
\end{tabular}

Freq - frequency;

Source: field survey, 2016. 
Ogunleye, A. S., Adeyemo, R. (2020). Social capital networks, microcredit and poverty status of rural households in Nigeria. J. Agribus. Rural Dev., 4(58), 369-378. http://dx.doi.org/10.17306/J.JARD.2020.01346

Table 4. Instrumental variable and aggregate social capital, microcredit and asset base correlation values

\begin{tabular}{lcccc}
\hline & Charity donation & Length of residence & Ethnic group membership & Religious group membership \\
\hline $\begin{array}{l}\text { Aggregate social } \\
\text { capital index }\end{array}$ & $0.100(P<0.05)$ & $0.005(P<0.05)$ & $0.029(P<0.05)$ & $-0.043(P<0.05)$ \\
Microcredit & Significant & Not significant & Not significant & Not significant \\
& $0.015(P<0.05)$ & $0.106(P<0.05)$ & $0.040(P<0.05)$ & $-0.079(P<0.05)$ \\
Asset base & Not significant & Significant & Not significant & Not significant \\
& $0.035(P<0.05)$ & $0.154(P<0.001)$ & $0.158(P<0.001)$ & $0.152(P<0.001)$ \\
& Not significant & Significant & Significant & Significant \\
\hline
\end{tabular}

Source: field survey, 2016.

in the study area. In about $88.90 \%$ of cases, the amounts of microcredit obtained from professional career groups ranged between $\$ 10,000.00$ and $\$ 100,000.00$. This implied that professional career groups were a reliable source of substantial amounts of microcredit in the study area. This was probably because most of their members are civil servants with regular salary packages, which encourages high savings. The average amount of microcredit obtained from religious groups was $\$ 7,453.70$ $( \pm \mathrm{N} 2,547.56)$. Such groups did not provide more than $\mathrm{N} 100,000.00$ of microcredit to its members per annum. This implied that the microcredit obtained from the religious groups was probably used to meet short-term consumption expenditure needs. The average volume of microcredit obtained from microfinance sources was $\mathrm{N} 11,022.00$ ( $\pm \mathrm{N} 4,791.13$ ). Such sources provided financial services to households that required less than N100,000.00 per annum. This was probably since most households opting to use microfinance groups may not have sufficient collateral securities to obtain high microcredit amounts.

\section{Test of endogeneity and validity of the instrumental variables}

A correlation analysis between each of the aggregate social capital indices, microcredit, the value of the households' asset base and the proposed instruments was carried out to test for the appropriateness and validity of the instrumental variables used in this section (Adepoju and Oni, 2012). Table 4 shows the result of the correlation analysis. It revealed that charity donation was significantly correlated $(0.100)$ with aggregate social capital while the duration of residence in the study area significantly correlated $(0.106)$ with microcredit.
Furthermore, the coefficients of residence duration (0.154), ethnic group membership (0.158) and religious group membership (0.152) showed significant correlations with the value of the household asset base. Therefore, the significant instrumental variables were used in the 2SLS analysis, the results of which are presented and discussed below.

\section{Effects of social capital and microcredit on household expenditure}

Table 5 shows the parameter estimates of the 2SLS regression model for the impact of social capital and microcredit on the household per capita expenditure. The Wald $\mathrm{Chi}^{2}$ (7) of $47.18 \%$ and the level of significance observed in the regression equation indicated that all the explanatory variables jointly affected the household per capita expenditure in the study area. This confirmed the suitability of the model. The result also showed that the coefficient of years of formal education $(\beta=417.69$, $p<0.05$ ) of the household head was positive and significantly influenced the household per capita expenditure in the study area. This implied that a one-unit increase in the head's years of education would increase the household's per capita expenditure by N417.69. This is consistent with the findings of Lam and Biu (2014). The household income coefficient $(\beta=0.16, p<0.01)$ also showed a positive and significant relationship with the household per capita expenditure in the study area. This implied that a one-unit increase in the household income would increase the household per capita expenditure by $\mathrm{N} 0.16$. This is consistent with the literature on incomeexpenditure relations according to Keynes' psychological laws of consumption (Jhingan, 2009). The coefficient of the amount of microcredit received $(\beta=0.04$, 

Agribus. Rural Dev., 4(58), 369-378. http://dx.doi.org/10.17306/J.JARD.2020.01346

Table 5. Impact of social capital and microcredit on household per capita expenditure

\begin{tabular}{|c|c|c|}
\hline Expenditure & Coefficient & Z-Statistics \\
\hline Constant & $-4526.095^{* *}$ & -2.28 \\
\hline Age (years) & 143.8681 & 0.48 \\
\hline Age-squared (years ${ }^{2}$ ) & -1.031628 & -0.40 \\
\hline Years of education (years) & $417.6852 * *$ & 2.57 \\
\hline Household income (N) & $0.1582621 * * *$ & 3.78 \\
\hline $\begin{array}{l}\text { Amount of microcredit } \\
\text { received }(\cong)\end{array}$ & $0.0360056^{*}$ & 1.80 \\
\hline Payback period (months) & 529.7317 & 0.99 \\
\hline $\begin{array}{l}\text { Aggregate social capital } \\
\text { index }(\%)\end{array}$ & $730.8344 *$ & 1.93 \\
\hline Number of observations & \multicolumn{2}{|l|}{300} \\
\hline Wald $\operatorname{Chi}^{2}(7)$ & \multicolumn{2}{|l|}{47.18} \\
\hline Prob $>\mathrm{Chi}^{2}$ & \multicolumn{2}{|c|}{0.0000} \\
\hline $\mathrm{R}$ - Square & \multicolumn{2}{|c|}{0.0534} \\
\hline Root MSE & \multicolumn{2}{|l|}{90753} \\
\hline
\end{tabular}

*Significance at $10 \%, * *$ significance at $5 \%$, and $* * *$ significance at $1 \%$ alpha levels.

Source: own elaboration.

$p<0.1)$ from the social capital network was positive and showed a significant relationship with the household per capita expenditure in the study area. This implied that a one-unit increase in the amount of microcredit received within the social capital network would increase the household per capita expenditure in the study area by $\$ 0.04$. This was in line with the a priori expectation and was consistent with findings of Lam and Biu (2014). The aggregate social capital index coefficient $(\beta=730.83$, $p<0.05)$ also showed a positive, significant relationship with the household per capital expenditure. The result indicated that a one-unit increase in the household social capital index would increase the household per capita expenditure in the study area by N730.83. This is consistent with the finding of Adepoju and Oni (2012).

\section{CONCLUSION}

This study investigated the effects of social capital and microcredit on the poverty status of rural households in south-western Nigeria. It concluded that there was a high level of poverty in the study area and that the household head's years of formal education, household size, payback periods, amount of microcredit received from social capital networks, microcredit processing time, cash contribution, meeting attendance, membership density and labour contribution indices were the major factors determining household poverty status in the area. It is important to emphasize that social capital networks have greatly contributed to improved microcredit access for households in the study area. Social capital and microcredit have positively influenced the household per capita expenditure and thus improved the poverty status of households in the study area.

\section{ACKNOWLEDGEMENTS}

The authors would like to gratefully acknowledge the support and cooperation provided by institutions, individuals, and other stakeholders.

The authors are especially grateful to:

- The Postgraduate College of the Obafemi Awolowo University, which provided funding in the form of tuition waiver during my $\mathrm{PhD}$ and field activities.

- All enumerators who participated in the field activities. Their dedication, meticulous attention to detail, and flexibility throughout the training and fieldwork are unparalleled.

- We would also like to thank various state and local government agricultural development programmes in the study area.

\section{REFERENCE}

Adepoju, A.A., Oni, O.A. (2012). Investigating Endogeneity Effects of Social Capital on Household Welfare in Nigeria: A Control Function Approach. Quart. J. Int. Agric., 51(1), 73-96.

Ajakaiye, O., Mwabu, G. (2007). The Production of Child Health in Kenya: A Structural Model of Birth Weight'. Conference paper on Economic Development in Africa, March 18-19, Center for the Study of African Economies. Mimeo: University of Oxford.

Awojobi, O., Bein, M.A. (2011). Micro financing for Poverty Reduction and Economic Development; a Case for Nigeria. Int. Res. J. Fin. Econ., 22(72), 159-168.

Balogun, O.L., Yusuf, S.A., Omonona, B.T., Okoruwa, V.O. (2011). Social Capital and Microcredit Effects on Poverty among Rural households in Southwest States, Nigeria. ARPN J. Agric. Biol. Sci., 6(3), 5-10. 
Ogunleye, A. S., Adeyemo, R. (2020). Social capital networks, microcredit and poverty status of rural households in Nigeria. J. Agribus. Rural Dev., 4(58), 369-378. http://dx.doi.org/10.17306/J.JARD.2020.01346

Bastelaer, V.T. (2000). Does Social Capital Facilitate the Poor's' Access to Credit? Social Capital Working Paper No. 8. The World Bank, Washington, DC.

CBN (2010). Central Bank of Nigeria Bulletin 2010. Retrieved Sep $30^{\text {th }} 2016$ from: www.cbn.gov.ng/rate/infates. asp?year $=2010$

Chen, S., Ravallion, M. (2010). The Developing World is Poorer than We Thought, But No Less Successful in the Fight against Poverty. World Bank Policy Research Paper 4703.

Conley, T., Udry, C. (2010). Learning about a new technology: Pineapple in Ghana. Am. Econ. Rev., 100(1), 35-69.

Osborn, D., Cutter, A., Ullah, F. (2015). Universal Sustainable Development Goals- Understanding the Transformational Challenge for Developing Countries Stakeholder Forum, May 2015. Retrieved Oct $10^{\text {th }} 2015$ from: https://sustainabledevelopment.un.org/content/documents/1684sf_Universality Report May 2015.pdf

Foster, J., Greer, J., Thorbecke, E. (1984). A class of decomposable poverty measures, Econometrica, 52, 761-766.

Hassan, R., Birungi, P. (2011). Social capital and poverty in Uganda. Dev. South. Afr., 28(10), 19-37.

Imandoust, S.B. (2011). Relationship between education and social capital. Int. J. Hum. Soc. Sci., 1(12), 52-57.

Iyanda, J.O., Afolami, C.A. Obayelu, A.E., Ladebo, O.J. (2014). Social Capital and Access to Credit among Cassava Farming Household in Ogun State, Nigeria. J. Agric. Env. Sci., 3(2), 175-196.

Jhingan, M.L. (2009). Macro Economic Theory ( $7^{\text {th }}$ Ed.). Delhi: Vrinda Publications.

JRF (2013). Monitoring poverty and social exclusion. Joseph Rowntree Foundation and the New Policy Institute.

Karlan, D., Mobius, M. Rosenblat, M.T., Szeidi, A. (2009). Trust and Social Collateral. Quart. J. Econ., 124(3), 1307-1361.

Karlan, D. (2007). Social connections and group banking. Econ. J., 117(517), 52-84.
Lam, T.V., Bui, B.A. (2014). Microfinance and Poverty Alleviation: Does Credit Access Contribute to Reduce Household Poverty in Vietnam, An Unpublished Masters Thesis. Faculty of Graduate School of Arts and Sciences of Georgetown University.

Lawal, J.O., Omonona, B.T., Ajani, O.I.Y., Oni, A.O. (2009). Effects of Social Capital on credit Access among Cocoa Farming Households in Osun State, Nigeria. Agric. J., 4(4), 184-191.

Meyer, D.B., Sullivan, X.J. (2003). Measuring the Well-Being of the Poor Using Income and Consumption,. A paper prepared for the Joint IRP/ERS Conference on Income Volatility and Implications for Food Assistance, May 2-3, 2002 in Washington, DC.

NBS (2010). The Nigeria Poverty Profile 2010 Report. National Bureau of Statistics.

Oke, J.T.O., Adeyemo, R., Agbonlahor, M.U. (2007). An Empirical Analysis of Microcredit Repayment in Southwestern, Nigeria. J. Hum. Soc. Sci., 2(1), 63-74.

Ravallion, M., Shaohua, C., Sangraula, P. (2009). Dollar a day. World Bank Econ. Rev., 23(2), 163-184.

Trading Economics (2016). Nigeria Population Data from 1960 to 2016. Retrieved Sep 30 2016 from: www. tradingeconomics.com/nigeria/population

Ugbaja, M., Ugwumba, C. (2013). Analysis of Microcredit as a Viable Tool in Poverty Reduction among Rural Farmers in Anambra State, Nigeria. Disc. J. Agric. Food Sci., $1(10), 152-159$.

World Bank (2014). Nigeria Economic Report. Working Paper No 2. July, 2014. Washington DC.

World Bank (2005). African Development Indicators 2005. New York: Oxford University Press.

World Bank Groups (2014). Age Dependency Ratio (\% of Working - Age Population). Retrieved Oct $19^{\text {th }} 2016$ from: www.Data.worldbank.org/indicator/SP.POP.DPND 